


\title{
Post-Soviet Russian Identity Building and Politics of Memory: Scientific and Public Discourse
}

\author{
DOI: https://doi.org/10.46398/cuestpol.3969.26
}

\author{
Svetlana Akhundovna Tatunts * \\ Anastasia Mikhailovna Ponamareva **
}

\begin{abstract}
The aim of the study was to examine the positions of various social groups, reflecting the controversial and contradictory aspects of the process of identity construction in post-Soviet Russia and the factor of memory politics. The article reveals the characteristics of the post-Soviet identity-building process and the related politics of memory under the century-end systemic transformation that has launched a new existential project in Russia. Collective identity is formed in a new social space: the global dichotomy of globalization and localization. Methodologically, it is a documentary research close to the analysis of discourse. The process of transition from the Soviet Union to post-Soviet space and the construction of the new state on the ruins of the socialist empire will keep the problems of a new identity and the politics of memory relevant soon. It is concluded that thirty years after the liquidation of the socialist project, the crisis of collective identity in Russia and the «battle for history» and a new Russian national unity are not over. However, persistent social atomization and conflict-triggering narratives of various socio-cultural communities and
\end{abstract} ideological groups persist.

Keywords: post-Soviet identity; instrumentalism; constructivism; historical narrative; World War II.

Doctor of Sociology, Ph. D. in Historical Sciences, Full Professor, World Politics Faculty, Lomonosov Moscow State University, Moscow, Russia. ORCID ID: https://orcid.org/o0oo-0002-0697-0847. Email: tatunts.s.a@mail.ru

** Assistant Professor of International Security Department, World Politics Faculty, Lomonosov Moscow State University, Moscow, Russia. Senior Researcher, Department of European Security, Center for Scientific Information Studies of Global and Regional Problems INION RAS, Moscow, Russia. ORCID ID: https://orcid.org/oooo-0o01-8370-3622. Email: ponamareva.a.m@mail.ru 


\section{Construcción de la identidad rusa postsoviética y política de la memoria: discurso científico y público}

\section{Resumen}

El objetivo del estudio fue examinar las posiciones de varios grupos sociales, reflejando los aspectos controvertidos y contradictorios del proceso de construcción de identidad en la Rusia postsoviética y el factor de la política de la memoria. El artículo revela las características del proceso de construcción de identidad postsoviética y las políticas relacionadas de la memoria bajo la transformación sistémica de fin de siglo que ha lanzado un nuevo proyecto existencial en Rusia. La identidad colectiva se forma en un nuevo espacio social: la dicotomía global de globalización y localización. En lo metodológico se trata de una investigación documental próxima al análisis del discurso. El proceso de transición de la Unión Soviética al espacio postsoviético y la construcción del nuevo estado sobre las ruinas del imperio socialista mantendrá la relevancia de los problemas de una nueva identidad y la política de memoria en un futuro próximo. Se concluye que treinta años después de la liquidación del proyecto socialista, la crisis de identidad colectiva en Rusia y la "batalla por la historia" y una nueva unidad nacional rusa no han terminado. Sin embargo, la atomización social persistente y las narrativas desencadenantes de conflictos de diversas comunidades socioculturales y grupos ideológicos persisten.

$\begin{array}{ll}\text { Palabras clave: } & \text { identidad postsoviética; instrumentalismo; } \\ & \text { constructivismo; narrativa histórica; segunda Guerra } \\ & \text { Mundial. }\end{array}$

\section{Introduction}

The collective self-identification of a nation is a multidimensional phenomenon, the study of which requires an interdisciplinary approach, without which it is impossible to come to empirically significant conclusions. An important element in the formation of national identity is historical politics, which we understand as the purposeful construction of images of the past by state and near state institutions. Globalization as a "new type of sociality" (Albrow, 1996) did not lead to the establishment of a universal historical metanarrative. "Wars of memory" accompany the formation of new states and the development of old ones, and the more clearly the prematurity of conclusions about the "death of an ethnos and nations" and the inevitability of political and cultural unification in the 21st century is highlighted. 
In this context, a researcher should consider the problem of collective self-identification of a nation taking into account such an essential feature of modern international relations as a combination of two opposite trends of globalization and localization, i.e., taking into account "globalization", in terms of R. Robertson (1992).

The issue of building national identity, as expected, acquired special relevance in Russia at the turn of the $20^{\text {th }}$ and $21^{\text {st }}$ centuries under the influence of those tectonic shifts that took place in the country, which until 1917 constituted the core of the Russian Empire, and then, until 1991, the Soviet Union. As V. Yadov (1994), one of the founders of Russian and Soviet sociology, wrote, post-Soviet Russia had to rethink its national identity and find in its historical past new "places of memory" capable of uniting a multiethnic society undergoing socio-political transformations and the loss of ideological orientations.

The purpose of this article is to preserve the "spirit of liberated independent research" (Goffman, 1959: 17), to highlight the key ideas of Russian academic discourse on the problem of the formation of a new postSoviet Russian identity, and also to analyze the specifics of state historical policy during the reign of V. Putin, as the longest-ruling leader of modern Russia.

\section{Materials and methods}

The source base of the study consists of articles by Russian experts on the issues of national identity, speeches by President V. Putin and certain normative legal acts of the Russian Federation.

The theoretical framework of the article is based on the works of domestic and foreign scientists who have made the greatest contribution to the development of the issue of identity and memory. Since the introduction of the concept of "identification" into science by S. Freud (1993) to explain the mechanism of emotional self-identification of an individual with a group, the problem field of identity research has significantly expanded and now has a stable interdisciplinary nature. This was facilitated by the development of the social psychologist E. Erikson (1968), the founder of the theory of small social groups C. Cooley, the American anthropologists R. Benedict, M. Mead and many others.

A significant element of the research toolkit was the concept of "collective representations" - collective feelings and ideas that ensure the unity and cohesion of the group - by the founder of structural functionalism, E. Durkheim. For the classicist of French sociology, who saw the defining trend in the development of society in the movement towards social solidarity, 
the unity of collective ideas and normative attitudes was the basis of a new structural independence (Durkheim, 1991). This idea is extremely relevant in the conditions of post-Soviet Russia, fragmented, highly stratified, where, as paradoxical as it may sound, the westernized power elite is trying to convince citizens separated from decision-making that they need to preserve their traditional spiritual and moral values.

Another semantic category of research is the concept of the "frame" by E. Goffman (1974: 40-43) as a kind of framework, an instrument for cognizing social reality, which helps individuals to gain social experience. The social environment forms social roles and social statuses, which E. Goffman calls masks. Frames, masks, symbolic interactions are extremely important for "closed" societies. E. Goffman (1963) is also the author of the theory of stigmatization, from which we borrow the idea of considering the relationship between virtual and real identity, taking into account the role of stigma in the process of socialization of an individual, and the connection between personal and social identity.

In fact, relying on E. Durkheim and following E. Goffman, the authors of the article avoid excessive psychologism, which is counterproductive for the purposes of this study. At the same time, the question of the role of "total institutions" in building social identity is raised tangentially.

"Total institutions" are represented as closed spaces, within which there is an individual with imposed social roles, belonging to certain reference groups. This "depersonalized man", as in the concept of M. Heidegger (1967) "das "Man" in everyday life, in the process of the formation of a person and society, acts and thinks "as it is accepted" - he is involved in this anonymous collective identity ... "A depersonalized man" is an object of influence of "total institutions", he is in the focus of state policy, including historical politics. It is included in the "participation" of Lucien Levy-Bruhl (1999: 20), who describes this process as "the imposition of collective identities of individuals," as a result of which they become "the product not of reasoning, but of faith".

Studies of Russian authors in all their ideological diversity seem to be relevant for this work. The traditions of Russian public discourse on the problem of identity were laid down by the Russian thinkers P. Chaadayev, N. Danilevsky, N. Berdyaev back in the tsarist period of history. On the basis of the dichotomous analysis West-East, Europe-Russia, the foundations of the concept of a special, almost super-original Russian identity and Eurasianism were formed (Danilevsky, 2008).

In Soviet historiography, the prevailing ideas and theories substantiated the formation of a new Soviet socialist identity, common for all peoples of the Soviet Union. The research methodology was firmly based on the ideas of the class approach in the spirit of K. Marx, V. Lenin and I. Stalin, 
therefore the identity could be either "proletarian" or "bourgeois".

Throughout the Soviet period, this methodology was rigorously observed in scientific literature. At the same time, the overwhelming majority of authors, when considering the problems of national identity, adhered to either sociobiological or cultural-historical primordialism (Bromley, 1977).

A significant break in the methodology of Russian research was noted at the end of the 1980 s and the beginning of the 1990s, when fundamental changes took place in the country and the Soviet Union collapsed. The opportunities of Russian scientists to get acquainted with the achievements of science in the field of studying the problems of identity and the politics of memory in Western countries have expanded. Despite the fact that Russian researchers have ceased to bypass the problems of conflicts, contradictions in relations between various ethnic and cultural groups, in the theoretical and methodological context, Russian science has not been enriched by heuristic achievements over many decades, and, in general, these developments are secondary (in relation to the results of Western scientists).

The analysis of the main body of post-Soviet scientific literature allows us to conclude that the majority of authors of the old Soviet school are committed to the cultural and historical direction of primordialism. It is gratifying that the works, sustained in the spirit of sociobiological primordialism, occupy a marginal position in Russian science. More and more authors share the constructivist concepts of identity and historical memory developed in Western science. The works of such Russian authors as I.S. Semenenko, L.M. Drobizheva, V.A. Tishkov, A.R. Dyukov, S.V. Akopov, V.I. Pantin, K.G. Kholodkovsky, A.A. Fadeeva are of particular interest. The results of research conducted by the Russian academic centers, such as the Institute of World Economy and International Relations, the Institute of Sociology of the Russian Academy of Sciences (Semenenko, 2017), are significant for achieving the goals of the article.

The research methodology is based on a polyparadigmatic approach to the development of this issue, which allows us to comprehensively cover the diversity of identity politics and historical memory in the context of postSoviet Russia, both in the academic field and in the public consciousness. Based on the phenomenological ideas of E. Husserl (1913), the connection between the present of post-Soviet Russia and its past in various models of discourse is shown.

\section{Research results}

“Third Rome" or "province" 
The range of assessments when discussing the problem of the collective identity of post-Soviet Russia is so wide that a comprehensive coverage of the topic within the framework of one article seems difficult. The research focused on academic discourse, including its comparison with public discourse, since they can be in opposition to each other.

At one pole of the discourse space, there is the thesis that in the modern world "Russia is a second echelon country. It is the last frontier that turns into a province" (Pigrov, 2018: 44). On the other, there is the idea, formed back in the era of Tsar Ivan IV the Terrible (16th century): "Russia is the third Rome, there will not be a fourth one," i.e. the savior of the whole world, the spiritual center of humanity.

Some, for the purpose of national consolidation, talk about the need to enforce the rationalism, characteristic of Western society, and criticism of the past. Others want self-identification based on tradition and sacred values.

It is noteworthy that for a part of society it is important to feel like heirs of Orthodox traditions, for others - Islamic ones. And these positions are trying to reconcile the supporters of the idea of Eurasianism.

\section{Permanent transformation of collective identity}

An attempt to present national identity as something objective, tangible and static is counterproductive. Changes occur in all dimensions of identity: narrative, cultural, religious, political and geographical. They have their own history and specificity of transformations.

Russia has repeatedly experienced stages of a crisis of collective identity, and the 2oth century is especially rich in this experience. At the end of the twentieth century representatives of the party and state apparatus declared themselves liberals and democrats and rushed to implement the project of a new Russia. Millions of people accepted the ideas of perestroika and democracy, but became disillusioned with reformers, who turned into oligarchs and businessmen with large accounts in offshore zones and found themselves in a state of social disorientation. In some regions of the country, social ties and structures have been so disrupted that this has led to the spread of ethnocentrism, racism and xenophobia. At the center of the ideological struggle there were the questions: "Who are we? Russians, Tatars, Christians, Muslims, former Soviet people?”

The intensity and goal-setting of the manifestation of collective identity have changed if we compare the post-Soviet and Soviet periods. 
In some regions of Russia, followers of Islam (both representatives of autochthonous peoples and labor immigrants from Muslim countries) explicate and deliberately emphasize their cultural and confessional specifics. Increasingly, as a result of re-Islamization (after decades of atheistic Soviet propaganda), religious rituals and traditions of these groups (Tatars, Bashkirs, Azerbaijanis and Uzbeks from among labor immigrants) are perceived as integral elements of culture, family history and clan. The scale of re-Islamization is such that in 2013, at the anniversary of the Central Spiritual Administration of Muslims of Russia, President V. Putin declared that "Islam is a bright element of the Russian cultural code" (NEWS.ru, 2013).

The national identity and the politics of memory (based on a negative attitude towards the Soviet past and designed by the elites in the 1990s) did not lead to the strengthening of social cohesion. Those citizens who in the last decades of the existence of the USSR demanded "changes" and "new turns" came to existential horror, faced with socio-economic reforms that accompanied political transformations. The process of transition from "homo post-Sovieticus" to a new collective identity lasted for decades; it was accompanied by manifestations of centrifugal processes in national republics, armed conflicts, social chaos and exacerbation of local "wars of memory".

\section{Who Constructs Identity?}

Speaking at the Valdai Discussion Club in 2013, President V. Putin acknowledged that the state and society are still in search of a new formula for post-Soviet identity, very productive for overcoming the Soviet past and remembering this experience, as was hoped for in the 1990s. Neither free elections, nor democracy, nor progress have freed society from the old structures of consciousness. The concept of post-Soviet identity is not articulated by the state, and the modern Russian nation is postulated as a "multiracial people" in the preamble to the Constitution of the Russian Federation, adopted in 1993 and edited in 2020 (Constitution of the Russian Federation, 2020: 2). The constituent parts of a large palette of subidentities - ethnic, regional, religious, and we understand that "identity, a national idea cannot be imposed from above" (Speech by Vladimir Putin, 2013).

It is obvious that the emancipating possibilities of the new bourgeois economic system were not sufficient - the once "united Soviet people" in the new Russia are still in a state of differentiation and fragmentation, which shows the incompleteness of the country's transit. 
Svetlana Akhundovna Tatunts y Anastasia Mikhailovna Ponamareva
Post-Soviet Russian Identity Building and Politics of Memory: Scientific and Public Discourse

So far, the political field of constructing a new collective identity is dominated only by the authorities, which are increasingly using commemorative practices as a tool for uniting society, exploiting the narrative nature of memory.

In the context of the still confrontational dichotomy of "ethnic - national identity", deep socio-economic polarization of society, wars of memory and social atomization, the state in the process of its self-identification faces a whole continuum of obstacles.

\section{Discussion}

With all the abundance of approaches to defining belonging to the "collective body" of a nation, the academic community proceeds from the idea that self-identification "is a matter of personal choice" - the thesis enshrined in the 32 Copenhagen Document of the Council on Security and Cooperation in Europe of 1990 (OSCE Copenhagen Commission, 1990: 20). This interpretation allows us not to fall into the sin of vulgar primordialism when discussing the problems of national identity.

An important mechanism for ensuring this self-identification, available to the power elites, is working with historical memory. The discourse of identity and memory in the Russian Federation has a high degree of emotional tension and reflects the state of the national dialogue between society and the state.

Following the concept of the social framework of memory by M. Halbwachs (2007), the authors believe that the "memorial boom" in postSoviet Russia was determined by the crisis of national identity due to the trauma of the collapse of the Soviet Union. Reconstruction of the past and working with memory occur in the country in the most plural modes.

Despite the fact that the article by E. Pain (2013), the head of the Center for the Study of Xenophobia and Extremism Prevention at the Institute of Sociology of the Russian Academy of Sciences, dedicated to historical fatalism in an era of timelessness (published in 2013), the author recorded the infection of Russian society with "déjà vu disease", which is expressed in the explanation of modern problems of the Fatherland mainly through the prism of the theory of "path dependency", has not disappeared to this day. The idea of a cultural predetermination of the Russian path is defended by two groups with fundamentally opposite ideological attitudes - the "guardians" and the "desperate". If the former substantiates the inadmissibility of political modernization as threatening the true national values, the latter would readily break out of the "Russian bureaucratic matrix", but consider this a priori impossible. 
The substantive aspects of the confrontation between the "guardians" and the "desperate" have remained unchanged over the past centuries. It is noteworthy that, guided by fundamentally opposite motives, both ideological groups ultimately contribute to the preservation of the existing political regime.

The authors can agree with E. Pain that when explaining the stability of elements of authoritarianism in Russia, Russian experts clearly exaggerate the role of traditions. Modern comparative studies show low rates of almost all forms of traditional group self-identification. We are not dealing with a continuous "social relay race" of values and norms, but with innovations disguised as traditions, i.e., with a phenomenon that the British theorist of nationalism Eric Hobsbawm (1992) called invented traditions. The influence of historical culture in Russia "is determined not so much by traditions as by their absence". At the same time, the importance of the resource economy factor (in which some scholars see the main source of cyclicality in the history of Russia) is secondary in relation to political factors and, above all, to the construction of the political system (Pain, 2013: 9-12).

Research facility of E. Pain is close to the position of A. Akhiezer, I. Klyamkin and I. Yakovenko. These experts explain the fluctuations between reforms and counter-reforms characteristic of Russia not by the specifics of the resource economy or the peculiarities of the national mentality, but by the direct and purposeful efforts of the political establishment to preserve itself.

E. Pain (2013: 13) criticizes the Russian ruling forces for their methods of cleaning up the information space in order to stabilize their own political monopoly. Accusing the Russian authorities of "spreading anti-Western hysteria", he represents what is happening as a kind of official Moscow initiative. However, today, as we observe an even greater increase in tensions in the same Russian-American relations, it becomes obvious that the restrictive measures taken by both sides reflect the complex opposition of rivalry and interdependence of the two powers. It seems that the consideration of the legislative and administrative initiatives of the Kremlin criticized by E. Pain without involving a broad foreign policy context turns into one-sided interpretations.

Recognizing the fact that Russian society is divided into ideological groups as accomplished and quite positive (in terms of avoiding the domination of the "amorphous mass of Soviet people"), E. Pain states the "poverty" of the set of political identifications that have been manifested. A team of experts, led by E. Pain, has compiled a political and ideological portrait of modern Russia in the course of analyzing the Runet. There were four recognizable "faces": liberal, leftist, nationalist and pro-government. Despite all the differences between these "faces", there are several signs that are common to all four currents: the prevalence of negative consolidation 
according to the principle "we are not them"; dissatisfaction with the current state of affairs; skepticism about the possibility of changing the situation for the better (Pain, 2013: 19). And the authors of the article find it extremely alarming that, in practice, xenophobia is the only platform for the potential unification of the mass audience of each of the four groups.

It should be noted that, given the increasing risk of new radical nonsystemic forces exploiting mass stereotypes on the political field, those in power should realize the depth of their personal responsibility for the decisions they make and stop blaming imperfections of the system of regulating socio-economic development on historically inherent structural restrictions.

Ethnopolitical scientist V. Achkasov (2015) states the lack of a positive program for the formation of national identity in the Russian Federation. Following the logic of the German historian of religion and culture Jan Assman (2004), he denotes the rootedness of identity, both ethnic and national, in historical memory, emphasizing that "manipulation of historical memory for political purposes, which is the essence of historical politics, is at the same time manipulations with group identity" (Achkasov, 2015: 182). However, the historical policy of the modern Russian state is defensive and reactive, and the power elites reveal a complete unpreparedness for a critical study of the past from the position of recognizing common responsibility for the tragic episodes of history.

The desire to avoid certainty in the assessments of historical figures and processes that cause heated debates in society, limits the repertoire of the "politically suitable" past available to state structures. Criticizing the instrumental approach of the authorities to the "collective past," V. Achkasov (2015: 189) points out that in the Russian Federation it is not a raw material for conducting a purposeful and methodical historical policy, but an object of situational use serving the purposes of legitimizing current decisions and actions of the elites. The total dependence on the current political environment explains the internal contradiction and eclecticism of the historical concept of modern Russian power, in which statism and nationalism are fancifully combined with elements of liberalism, and restoration pathos - with the idea of modernization.

Consolidation of the nation is carried out mainly on a negative basis, through the use of the image of the enemy, which, in principle, seems to be typical for all states of the post-Soviet space. V. Achkasov argues that more than twenty years after the collapse of the USSR, Russia still has not succeeded in forming a concept of national history that would meet the challenges of constructing its new collective identity. The key to a successful solution is not in an apophatic approach to defining the essence of the national, not in a strategy of silence, but in the formation of an environment in which discussions on controversial issues of common history and 
competing interpretations of historical events and facts would be allowed. As noted by the American economist P. Katzenstein:

(..). while we adhere only to national nationalist history and until we succeed in combining different types of history, we remain prisoners of the past. After all, only a common understanding of the past can create the basis for a common sense of the future (Dutkevich and Sakwa, 2014: 285, 284).

In view of the above, V. Titov's analysis of the key theoretical and practical aspects of the implementation of the "policy of memory" in Russia in relation to solving the problem of forming a cohesive nation deserves detailed consideration (Titov, 2017). Using the potential of constructivist and macro-political approaches, V. Titov formulates his own vision of national-state identity, presenting it as a political phenomenon that reveals itself in the synthesis of cognitive, temporal, emotional, and symbolic fields. The effectiveness of the state "policy of memory" in the context of nationalstate identity is determined through an assessment of its elasticity: the ability to rely on ideas and stereotypes already established in society and to take into account the existing emotional climate. It is especially emphasized that the policy of modern states, aimed at the formation of national-state identity, is carried out in the context of global information and sociocultural competition, in a situation of the large-scale political "market of identities", within which a wide range of alternative social and political identities of local, regional, and transnational level (Titov, 2017: 12-41).

V. Titov identifies four stages of the institutional evolution of the state policy of memory in the period from 1990 to 2010s: "anti-Soviet" (1992-1994); "Late Yeltsin" (1995-2000); "Early Putin" (2001-2008); "Medvedev-Putin" (since 2009), as the passage of which increases the intensity of turning to history in order to build the geopolitical and sociocultural foundations of the all-Russian national and state identity. Nevertheless, his demarcation is nothing more than a methodological technique and it does not negate the need to build continuity of the memory policy in post-Soviet Russia, including in the context of assessments of the Soviet experience (Titov, 2017: 59-105).

V.V. Titov attributes the disadvantages of the memory policy implemented in the country today to the cognitive weakness of the image of the past in the "matrix" of the Russian national and state identity; amorphousness of mass perceptions of the past; attempts to build them "like a chessboard", mechanically combining "black" and "white". This approach avoids conflicts, but a priori dooms the image of Russian history to fragmentation.

However, the modern historical policy of the Russian authorities from outside is seen as much more rational and thoughtful. It would 
be appropriate to compare V. Titov's conclusion with observations of the German historian M. Edele, who analyzed the "wars of memory" of President V. Putin. He drew attention to the fact that the cornerstone of state historical policy under Putin was the work with the narrative about World War II (Edele, 2017).

This conclusion is also confirmed by domestic experts. As I. Kurilla noted, in the Russian Federation:

\begin{abstract}
(...) the history of the Great Patriotic War has become ... a universal language of conversation about politics and the only effective "bond"... It is the narrative of the war that the Kremlin seeks to control first and foremost from the point of view of the interests of the regime (Kurilla, 2018: 39).
\end{abstract}

The World War II narrative in the modern Russian Federation is based on several strong points. First, the USSR seems to be the unambiguous victim in this story. Secondly, the "Patriotic war of liberation against the fascist enslavers" is positioned as a battle for the liberation of the entire world from National Socialism.

It is important to emphasize that for the citizens of the USSR, as well as for Russia, this Second World War has always been, first of all, the Great Patriotic War. It determines the discrepancy between Russian and foreign historiography in determining the starting date of World War II. For most Russians, this is June 22, 1941, when the troops of Nazi Germany "without a declaration of war, suddenly attacked the entire western border of the Soviet Union and inflicted bombing air strikes on Soviet cities and military formations". Few people remember the Japanese invasion of Central China in 1937. The date of September 1, 1939, which has become established in European social science, is widely regarded by many as imposed from the outside by those who seek to prove that the USSR is guilty of inciting war to the same extent as Nazi Germany.

Working with collective memory helps the authorities in the confrontation with opponents both at home and abroad. The "Russian" version of World War II has been turned into the cornerstone of a positive national narrative. In this context, the toughening of memorial legislation should be viewed as an element of immunization of Russian society against the virus of "velvet revolutions".

The Western media did not immediately realize the full political significance of the law signed by the President of the Russian Federation on May 5, 2014, criminalizing the rehabilitation of Nazism. Namely: for public denial of the facts established by the verdict of the International Military Tribunal for the trial and punishment of the main war criminals of the European Axis countries; approval of the crimes established by 
the verdict, as well as the dissemination of deliberately false information about the activities of the USSR during the Second World War, committed publicly. For these acts, a fine of up to 300 thousand rubles is provided or in the amount of the convicted person's income for a period of up to two years, or forced labor for up to three years, or imprisonment for the same period (Federal Law of the Russian Federation, 2014). With the adoption of this law, a kind of criminalization of freedom of expression occurred in the Russian Federation, which does not coincide with the state ideological narrative.

During his second presidential term, V. Putin spoke out on a number of controversial and potentially divisive issues of history that he had previously deliberately avoided addressing. He admitted that the apparent cruelty of the Stalinist system can be considered historically justified, because the defeat of the USSR in World War II (possible under a more liberal regime) would lead to catastrophic consequences for the whole world (Edele, 2017).

By 2015, V. Putin had developed a clear scenario for presenting the Great Patriotic War as part of the heroic history of modern Russia. The key components of this "myth" were the following statements: the USSR victoriously ended the war against fascism; Russia played a key role in World War II; all negative "moments" were due to historical necessity, normal in the context of that time and insignificant in comparison with the cruelty of other states; Russia can be proud of its past, and anyone who does not share this opinion is a foreign agent or an accomplice of foreign agents.

Armed with this basic narrative, Russia began a series of commemorative events dedicated to the 7oth anniversary of the end of World War II and the victory over Nazi Germany.

The interpretation of World War II, chosen by V. Putin, is in many ways more complex and complex than the one that the former leaders of the state adhered to. The current President of the Russian Federation does not deny the obvious facts, but emphasizes the speculative and incorrect unambiguous division into "black" and "white". So, for example, having subjected the Molotov-Ribbentrop Pact to moderate criticism, V. Putin called on the international community not to consider it the only trigger of World War II, pointing out that the Munich Agreement of 1938 played a similar role. As I. Torbakov (2014) noted, the prevalence of a certain attitude to history in the Russian Federation cannot be inscribed in the primitive formula "The Kremlin is washing the brain of a defenseless population". Rather, we find "a convergence of the vision of the managers and the governed in Eurasia".

V. Putin's initiatives can be considered as a counterattack in the space of the international "battle for the past", where in recent years Russia has been always assigned the role of a defending side. In 2009, such a step was 
the establishment of the Commission under the President of the Russian Federation to counteract attempts to falsify history to the detriment of Russia's interests, which existed until 2012. But this Institute remained rather "toothless": its functions were limited to the synthesis and analysis of relevant information, as well as the development of recommendations. The 2014 Memorial Law certainly has great potential for impact.

V. Putin and his team believe that for a better future, the country needs a monolithic, heroic narrative. In the space of historical memory, democratic and authoritarian political projects collide, and society is polarized.

\section{Conclusion}

Summing up, we note that in the historical series of ontological issues that torment the minds of Russians for at least two centuries, to the textbook - "What is to be done?" and "Who is to blame?" - added the question "Who are we?" If in the definition of the Great Patriotic War as the most important "assemblage point" of the nation, there is a consensus of the power elites, then there is no such agreement regarding the ideological foundations and the vector of the future development of the state. Citizens in their attempts at self-determination sometimes slip into confrontational modes. The scientific community is split in its assessments of the past and the future. All this testifies to the crisis state of the collective identities of post-Soviet Russia, to the fact that a way out of the ideological impasse has not yet been found. The civic self-identification of Russians has a shaky cognitive basis in terms of the ability to rely on a set of consistent ideas about the country's identity and past.

Despite the fact that the academic community of this or that platform raises the question of the need for a holistic structuring of the narrative about the past, while the authorities interpret this task in a utilitarian instrumental key: more as a measure of counteraction to attempts to falsify Russian history, both from domestic and foreign opponents. How long this symbolic resource will be sufficient for the construction of a solidary national identity in the long term, only time will give the answer.

\section{Bibliographic References}

ACHKASOV, Valery Alekseevich. 2015. "The role of "historical politics,, in the formation of Russian identity" In: Journal of Sociology and Social Anthropology. No. 2, pp. 181-192. 
ALBROW, Martin. 1996. The Global Age: State and Society beyond Modernity. Stanford University Press. Stanford, USA.

ASSMAN, Jan. 2004. Cultural memory: Writing, memory of the past and political identity in the high cultures of antiquity. Languages of Slavic culture. Moscow, Russia.

BROMLEY, Yulian Vladimirovich. 1977. Rapprochement of the social-class structure of the Soviet nations. Nauka. Moscow, Russia.

THE CONSTITUTION OF THE RUSSIAN FEDERATION. 2020. Eksmo. Moscow, Russia.

DANILEVSKY, Nikolay Ya. 2008. Russia and Europe: a look at the cultural, historical and political relations of the Slavic world to the GermanRoman. ABC-Classics. St. Petersburg, Russia.

DURKHEIM, Emile. 1991. On the division of social labor. Sociological methods. Nauka. Moscow, Russia.

DUTKEVICH, Petr; SAKWA, Richard. 2014. (Eds.). "Peter Katzenstein talks with Raffaele Marchetti "Understand that there is a diffusion of power and changes are constantly occurring"' In: 22 ideas on how to arrange the world: Conversations with prominent scientists. Moscow State University. Moscow, Russia.

EDELE, Mark. 2017. "Fighting Russia's history wars. Vladimir Putin and the codification of World War II" In: History and Memory. Vol. 29, No. 2, pp. 90-124.

ERIKSON, Erik. 1968. Identity: Youth in Crisis. W. W. Norton Company. New York, USA.

FEDERAL LAW OF THE RUSSIAN FEDERATION No. 128-FZ. 2014. "On Amendments to Certain Legislative Acts of the Russian Federation". Available online. In: http://publication.pravo.gov.ru/Document/ View/0001201405050051?index=. Consultation date: 03/08/2020.

FREUD, Sigmund. 1993. Massenpsychologie und Ich-Analyse. Die Zukunft einer Illusion. Fischer. Frankfurt am Main, Germany.

GOFFMAN, Erving. 1974. Frame Analysis: An Essay on the Organization of Experience. Harper and Row. New York, USA.

GOFFMAN, Erving. 1963. Stigma. Notes on the Management of Spoiled Identity. Prentice-Hall. Englewood-Cliffs. New Jersey, USA. 
Svetlana Akhundovna Tatunts y Anastasia Mikhailovna Ponamareva

GOFFMAN, Erving. 1959. The Presentation of Self in Everyday Life. Hamondsworth Pengium. New York, USA.

HALBWACHS, Maurice. 2007. Social memory framework. Tr. by S.N. Zenkina. New publishing house. Moscow, Russia.

HEIDEGGER, Martin. 1967. Sein und Zeit. 11 Auflage. Max Niemeyer Verlag. Tübingen, Germany.

HOBSBAWM, Eric; RANGER, Terence. 1992.(Eds.). The Invention of Tradition. Cambridge University Press. Cambridge, United Kingdom.

HUSSERL, Edmund. 1913. Ideen zu einer reinen Phänomenologie und phänomenologischen Philosophie. Erstes Buch: Allgemeine Einführung in die reine Phänomenologie. Max Niemeyer Verlag. Halle (Saale), Germany. Available online. In: https://www.freidok.uni-freiburg.de/ fedora/objects/freidok:5973/datastreams/FILE1/content. Consultation date: $01 / 08 / 2020$.

KURILLA, Ivan. 2018. Immortal regiment ":Holiday with tears in your eyes “, a parade of the dead or a mass protest? Disputes about the meaning and prospects of the new holiday ritual. Available online. In: http://www. ponarseurasia.org/ru/article_20180620_Kurilla. Consultation date: 02/08/2020.

LEVY-BRUHL, Lucien. 1999. Supernatural in primitive thinking. Pedagogy Press. Moscow, Russia.

NEWS.ru. 2013. Putin called Islam "a bright element of the Russian cultural code”. Available online. In: https://www.newsru.com/religy/220ct2013/ ufa.html. Consultation date: 03/08/2020.

OSCE COPENHAGEN COMMISSION. 1990. Document of the Copenhagen Meeting of the Conference on the Human Dimension of the CSCE. Organization for Security and Cooperation in Europe. Available online. In: https://www.osce.org/files/f/documents/d/o/14305.pdf. Consultation date: $02 / 08 / 2020$.

PAIN, E.A. 2013. "Historical fatalism in the period of stagnation" In: Bulletin of public opinion. Data. Analysis. Discussions. Vol. 115, No. 22, pp. 7-19.

PIGROV, Konstantin Semenovich. 2018. "Russian people's selfconsciousness: national culture and mass civilization” In: EINAI: Philosophy. Religion. Culture. Vol. 7, No. 1(13), pp. 37-56.

ROBERTSON, Roland. 1992. Globalization: Social Theory and Global Culture. Sage Publications Ltd. Thousand Oaks, London, United Kingdom. 
SEMENENKO, Irina Stanislavovna. 2017. (Ed.). Identity: Personality, society, politics. Encyclopedic edition. Ves Mir Publishing House. Moscow, Russia.

ROSSIYSKAYA GAZETA. 2013. Speech By Vladimir Putin At A Meeting Of The Valdai Club. 2013. Available online. In: https://rg.ru/2013/o9/19/ stenogramma-site.html. Consultation date: 02/08/2020.

TITOV, Victor Valerievich. 2017. The policy of memory and the formation of national-state identity: Russian experience and new trends. Printing House "Vash Format". Moscow, Russia.

TORBAKOV, Igor. 2014. "Divisive Historical Memories: Russia and Eastern Europe" In: Confronting Memories of World War II: European and Asian Legacies. Eds. Daniel Chirot, Gi-Wook Shin and Daniel Sneider. University of Washington Press. Seattle, USA.

YADOV, Vladimir A. 1994. "Social identification in a crisis society" In: Sociological journal. No. 1, pp. 35-52. 
Vol. 39 N $^{\circ} 69$

Esta revista fue editada en formato digital y publicada en julio de 2021, por el Fondo Editorial Serbiluz, Universidad del Zulia. Maracaibo-Venezuela 